\title{
The effect of digest acid on growth rate and some blood parameters in calves
}

\author{
Danuta Strusińka, Stefania Iwańska and Barbara Pysera \\ Institute of Animal Nutrition and Feed Managament, \\ Olsztyn University of Agriculture and Technology \\ 10-718 Olsztyn, Poland
}

\begin{abstract}
Analyses were carried out of the growth rate and concentration of some metabolites in blood serum of calves. The animals were fed diets supplemented with digest acid (a mixture of lactic, citric and orthophosphoric acids). It was shown that diet supplementation with this acid, used from calf birth till day 84 of life, had a beneficial effect on animal growth and increased uptake of the compound mixture already from day 22 of life.

When the animals were fed only solid feeds, acid supplementation improved nutrient utilization, this being reflected in an increase in the concentration of some indices related to lipid, protein and carbohydrate metabolism.
\end{abstract}

KEY WORDS: calves, digestive acid, body weight, blood serum

\section{INTRODUCTION}

Various feed supplements are used in animal breeding in order to improve nutrient utilization and to increase animal resistance to unfavourable environmental conditions.

Feed supplements, in the form of organic acids, increase acidity in the digestive tract environment, thereby inhibiting development of pathogenic bacteria and improving animal health. It was found that pig diet supplementation with organic acids increased secretion of digestive cnzymes and improved protein and energy retention, thereby improving the effects of animal production (Borowiec et al., 1996; Jacyno, 1996). There are, however, no data on the use of organic acids in calf feeding, whereas these animals frequently suffer from diarrhoea caused by the development of pathogenic bacteria in their digestive tract. 
In view of this, studies were undertaken to determine the effect of digest acid (a mixture of organic acids: lactic and citric, and an inorganic orthophosphoric acid) on growth rate, solid feed ingestion and some parameters of blood serum in calves.

\section{MATERIAL AND METHODS}

Studies were carried out on 20 Black-and-White Lowland calves from birth till day 84 of life. The animals were divided into 2 groups ( 10 in each group) and were kept and fed individually.

After the first uptake of colostrum, the calves were given whole milk till day 21 , and from day 22 till day 60 - a milk substitute. Calves aged 61-84 days were fed compound mixture and meadow hay only. Beginning from the 7 th day of life the animals were given ad libitum access to solid feeds (compound mixture and hay).

All calves were also given a vitamin-mineral premix at the rate of $1 \mathrm{~g}$ daily (1-15 day of life), $2 \mathrm{~g}$ (16-60 day of life) and $3 \mathrm{~g}$ (61-84 day of life). Premix composition (in $1 \mathrm{~g}$ ): vit $\mathrm{A}-10.000$ i.u., vit. $\mathrm{D}_{3}-800$ i.u. and $\mathrm{mg}$ of vit. $\mathrm{E}-40$; vit. $\mathrm{K}_{3}-0.6$; vit. $\mathrm{B}_{1}-0.8$; vit. $\mathrm{B}_{2}-2.0$; vit. $\mathrm{PP}-2.4$; vit. $\mathrm{B}_{5}-2.4$; vit. $\mathrm{B}_{6}-1.6$; choline - 4.0; methionine -2.0 ; lysine -4.0 ; mineral chelates: $\mathrm{Mn}-5.0$; $\mathrm{Fe}-1.0$; $\mathrm{Cu}-0.25 ; \mathrm{Co}-0.06 ; \mathrm{Zn}-3.0 ; \mathrm{Mg}-1.0 ; \mathrm{Se}-0.15$.

Each calf in group 2 (experimental) aged 1 to 84 days was also given $4 \mathrm{~g}$ daily of digest acid (a mixture containing organic acids: lactic and citric, and an inorganic orthophosphoric acid, produced by Compagnie Chimique d'Aquitaine, France).

Body weight, feed ingestion and animal health were controlled throughout the experiment.

Analyses of the content of total protein, AST, ALT, glucose, total lipids, triglyceride, cholesterol, phospholipids and free fatty acids in blood serum were made in blood samples collected from the jugular vein immediately after calf birth (before first colostrum feeding) and on days 21,60 and 84. The results were treated statistically.

\section{RESULTS AND DISCUSSION}

Data presented in Table 1 reveal that the rate of animal growth in the first 3 weeks of life was high and similar in both groups. Later on growth rate was morc diversified. In the period when the animal diet was changed from whole milk to milk substitute (from 22 nd till 60 th day of life), growth rate became inhibited. These data support the suggestions of other authors (Pysera et al., 1992; Bilik, 
TABLE 1

Body weight, daily growth and solid feed intake in calves

\begin{tabular}{|c|c|c|c|c|}
\hline \multirow[t]{2}{*}{ Specification } & \multicolumn{4}{|c|}{ Groups } \\
\hline & \multicolumn{2}{|c|}{$\mathrm{I}$} & \multicolumn{2}{|c|}{2} \\
\hline \multicolumn{5}{|l|}{ Body weight, $\mathrm{kg}$} \\
\hline - newborn & 40.8 & 2.1 & 38.0 & 2.7 \\
\hline-21 days & $58.1^{\mathrm{b}}$ & 2.0 & $52.0^{\mathrm{a}}$ & 2.8 \\
\hline-60 days & 76.8 & 2.5 & 79.6 & 3.6 \\
\hline-84 days & $97.7^{\mathrm{a}}$ & 2.3 & $103.9^{\mathrm{b}}$ & 3.7 \\
\hline \multicolumn{5}{|l|}{ Daily weight gain, g } \\
\hline 1-21 days & 754 & 9 & 745 & 11 \\
\hline $22-60$ days & $471^{\wedge}$ & 10 & $619^{\mathrm{B}}$ & 12 \\
\hline $61-84$ day & $911^{\mathrm{A}}$ & 16 & $1044^{\mathrm{B}}$ & 15 \\
\hline 1-84 days & $666^{a}$ & 11 & $760^{\mathrm{b}}$ & 9 \\
\hline \multicolumn{5}{|c|}{ Fced intake, $\mathrm{kg}$ ( $7-84$ days) } \\
\hline - compound mixture & $36.2^{\mathrm{A}}$ & 4.2 & $58.7^{\mathrm{B}}$ & 6.4 \\
\hline - meadow hay & 28.3 & 3.9 & 22.5 & 3.2 \\
\hline
\end{tabular}

$\mathrm{a}, \mathrm{b}=\mathrm{P}<0.05 ; \mathrm{A}, \mathrm{B}=\mathrm{P}<0.01$

1996) that growth rate decreases when calves are transferred to milk substitutes. Notwithstanding this, daily weight increments in the experimental group were $31 \%$ higher than in the control, suggesting a beneficial effect of diet supplementation with digest acid. This is confirmed by higher (by 14\%) weight increments observed in the experimental group in the period when only solid feeds were used (days 61-84 of calf life). These differences in weight of increments affected the final weights of the animals; in group 2 the mean individual weight at the end of the experiment was $69.5 \mathrm{~kg}$, i.e. $13.5 \%$ higher than in the control group 1. It should be also underlined that calves in group 2 ingested $62 \%$ more compound mixture compared to the control animals. Thus, it can be assumed that acid addition improved also feed palatability.

Some biochemical indices of blood serum at animal birth and on days 21, 60 and 84 are presented in Tables 2 and 3.

The lowest levels of total protein, AST and ALT were found in newborn calves. The same was found by Grodzki et al. (1991). In later periods of animal life the concentration of these substances in blood serum increased more systematically in group 2. Higher contents of protein, AST and ALT in 12-week old calves receiving digest acid suggest its beneficial effect not only on protein utilization, but also on the utilization of other nutrients in the solid diet (compound mixture and hay). This suggestion is confirmed by the higher (by over $30 \%$ ) content of glucose in calves from group 2 aged 60 and 84 days. In the control group, the highest glucose concentration in blood serum was observed on the 21 st day of life, viz. when the animals still received whole milk. 
TABLE 2

Concentrations of total protein, AST, ALT and glucose in blood serum of calves

\begin{tabular}{|c|c|c|c|c|c|c|c|c|}
\hline \multirow{4}{*}{ Specification } & \multicolumn{8}{|c|}{ Groups } \\
\hline & \multicolumn{5}{|c|}{1} & \multicolumn{3}{|c|}{2} \\
\hline & \multicolumn{8}{|c|}{ age of calves, days } \\
\hline & newborn & 21 & 60 & $84 n$ & newborn & 21 & 60 & 84 \\
\hline \multirow{2}{*}{ Total protein $\mathrm{g} / \mathrm{l}$} & 52 & 75 & 93 & 89 & 52 & 65 & 87 & 95 \\
\hline & 2 & 3 & 7 & 5 & 12 & 14 & 8 & 6 \\
\hline \multirow[t]{2}{*}{ AST i.u. $/ 1$} & 28.9 & 30.0 & 30.2 & 35.1 & 28.3 & 31.7 & 31.3 & 35.5 \\
\hline & 1.7 & 1.9 & 2.3 & 2.7 & 1.9 & 2.6 & 2.8 & 2.9 \\
\hline \multirow[t]{2}{*}{ ALT i.u./l } & 15.5 & 15.8 & 15.9 & 19.9 & 12.3 & 16.4 & 18.0 & 22.7 \\
\hline & 1.1 & 1.0 & 1.3 & 2.1 & 1.2 & 1.7 & 1.4 & 2.6 \\
\hline \multirow[t]{2}{*}{ Glucose $\mathrm{mmol} / \mathrm{l}$} & 1.95 & 2.45 & $2.25^{a}$ & $2.25^{\mathrm{a}}$ & 2.07 & 2.04 & $3.40^{b}$ & $3.25^{\mathrm{h}}$ \\
\hline & 0.32 & 0.71 & 0.24 & 0.14 & 0.91 & 0.20 & 0.33 & 0.76 \\
\hline
\end{tabular}

$\mathrm{a}, \mathrm{b}=\mathrm{P}<0.05$

TABLE 3

Concentrations of total lipids and lipid classes in blood serum of calves

\begin{tabular}{|c|c|c|c|c|c|c|c|c|}
\hline \multirow{4}{*}{ Specification } & \multicolumn{8}{|c|}{ Groups } \\
\hline & \multicolumn{5}{|c|}{1} & \multicolumn{3}{|c|}{2} \\
\hline & \multicolumn{8}{|c|}{ age of calves, days } \\
\hline & newborn & 21 & 60 & $84 \mathrm{n}$ & newborn & 21 & 60 & 84 \\
\hline \multirow[t]{2}{*}{ Total lipids mg/dl } & $101.2^{\circ}$ & $304.4^{\mathrm{A}}$ & $248.5^{B}$ & $225.7^{\mathrm{B}}$ & $101.8^{\circ}$ & $319.1^{\mathrm{A}} \quad 2$ & $227.6^{\mathrm{H}} \quad 2$ & $239.8^{\mathrm{B}}$ \\
\hline & 30.0 & 38.6 & 36.1 & 36.5 & 25.0 & 32.7 & 29.6 & 20.1 \\
\hline \multirow[t]{2}{*}{ Triglycerides mmol/1 } & $0.24^{\mathrm{C}}$ & $0.66^{\wedge}$ & $0.38^{13}$ & $0.38^{13}$ & $0.23^{\mathrm{C}}$ & $0.68^{\mathrm{A}}$ & $0.39^{\mathrm{H}}$ & $0.37^{\mathrm{B}}$ \\
\hline & 0.08 & 0.11 & 0.06 & 0.07 & 0.07 & 0.14 & 0.08 & 0.10 \\
\hline \multirow[t]{2}{*}{ Total cholesterol mmol/1 } & $0.63^{A}$ & $2.20^{\mathrm{Ba}}$ & $2.18^{\mathrm{Ba}}$ & $2.52^{\mathrm{ka} a}$ & $0.59^{A}$ & $2.59^{\mathrm{Bb}}$ & $2.55^{\mathrm{Bh}}$ & $2.81^{\mathrm{Bb}}$ \\
\hline & 0.09 & 0.43 & 0.26 & 0.37 & 0.16 & 0.16 & 0.25 & 0.28 \\
\hline \multirow[t]{2}{*}{ Phospholipids mmol/1 } & $0.50^{\wedge}$ & $1.55^{\mathrm{B}}$ & $1.36^{\mathrm{B}}$ & $1.41^{13}$ & $0.43^{\mathrm{A}}$ & $1.68^{\mathrm{B}}$ & $1.22^{\mathrm{B}}$ & $1.42^{\mathrm{B}}$ \\
\hline & 0.04 & 0.36 & 0.25 & 0.28 & 0.05 & 0.25 & 0.20 & 0.34 \\
\hline \multirow[t]{2}{*}{ NEFA mmol/l } & $0.76^{\Lambda}$ & $0.35^{\mathrm{B}}$ & $0.22^{\mathrm{B}}$ & $0.20^{13}$ & $1.13^{\mathrm{A}}$ & $0.43^{\mathrm{B}}$ & $0.18^{13}$ & $0.18^{\mathrm{B}}$ \\
\hline & 0.15 & 0.13 & 0.06 & 0.05 & 0.15 & 0.09 & 0.04 & 0.03 \\
\hline
\end{tabular}

$\mathrm{a}, \mathrm{b}=\mathrm{P}<0.05 ; \mathrm{A}, \mathrm{B}, \mathrm{C}=\mathrm{P}<0.01$

Similar to the studies by Blum et al. (1997), the levels of total lipids, triglycerides and phospholipids were lowest in the newborn calves. High concentrations of easily digestible components in the colostrum and in whole milk resulted in high lipid content in blood serum of calves aged 21 days. 
Lipid metabolism changed when the animals were transferred to milk substitutes and then to solid feeds (Leplaix-Charlat et al., 1996). The concentration of total lipids and triglycerides decreased in both groups by 25 and $42 \%$, respectively, compared to the levels observed in 21 day old animals. There was, however, no decrease of phospholipids or cholesterol. From the 3rd week of life onward, the cholesterol concentration was $15 \%$ higher in calves receiving acid supplementation than in the control group. It was also shown that the concentration of free fatty acids was the highest in newborn calves, and then gradually decreased in all animals. The same was observed by Leplaix-Charlat et al. (1996) and Hadorn et al. (1997).

It can be concluded that diet supplementation with digest acid, applied from calf birth till day 84 , had a beneficial effect due to:

- increased growth rate of the animals,

- increased uptake of compound mixture already by the $22^{\text {nd }}$ day of life,

- higher concentration of some metabolites in the blood serum (glucose, ALT, total lipids, cholesterol), especially when the calves were fed solid feeds.

\section{REFERENCES}

Bilik K., 1996. Using various milk feeding systems and feeding according to INRA standard in rearing Black-and-White Lowland heifer calves with various proportions of the Holstein-Fresian genotype (in Polish). Roc7. Nauk. Zoot. 23 (1), 159-174

Blum J.W., Hadorn U., Sallmann H.P., Schuep W., 1997. Delaying colostrum intake by one day imparis plasma lipid, essential fatty acid, carotene, retinol and $\alpha$-tocopherol stasus in neonatal calves. J. Nutr. 127, 2024-2029

Borowiec F., Furgał K., Sapata M., Micek P., 1996. The effect of Cylactin and Cytronic on the performance of growing pigs (in Polish). Proceedings of XXVI Scientific Session of the Animal Feeding, Commission of the Committee of Zootechniques, Polish Academy of Sciences, on „Food additives in animal feeding”. Olsztyn, Poland, pp. 46-48

Grodzki K., Lechowski R., Lenarcik M., 1991. The biochemical profile of calves liver in the course of diarrhoea during the first 10 days of life (in Polish). Pol. Arch. Wet. 31 (3-4), 49-63

Hadorn U., Hammon H., Bruckmaier R.M., Blum J.W., 1997. Delaying colostrum intake by one day has important effects on metabolic traits and on gastrointestinal an metabolic hormones in neonatal calves. J. Nutr. 127, 2011-2023

Jacyno E., 1996. Biological food additives in pig feeding (in Polish). Proceedings of Conference on „Food additives as production stimulators for domestic animals”, Szczecin - Barzkowice, Poland, pp. 40-43

Leplaix-Charlat L., Bauchart D., Durand D., Laplaud P.M., Chapman J.M., 1996. Plasma lipoproteins in preruminant calves fed diets containing tallow or soybean oil with and without cholesterol. J. Dairy Sci. 79, 1267-1277

Pysera B., Iwańska S., Strusińska D., 1992. The influence of natural or synthetic $\beta$-carotene addition on fooder utilization and results of rearing in calves (in Polish). Acta Acad. Agic. Tech. Olst. $36,25-33$ 